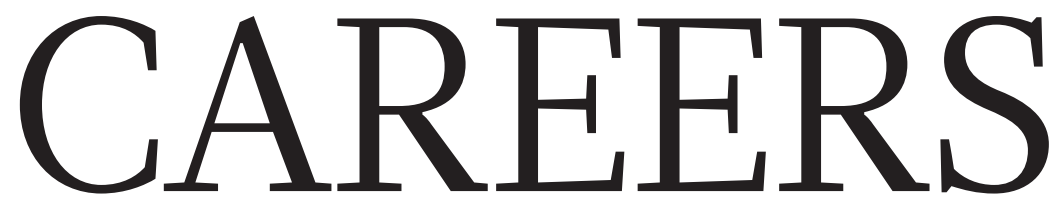

CAREER TOOL KIT Access key resources to craft a successful career go.nature.com/5lzhj6

CAREERS ADVICE FORUM Get expert advice on science careers issues go.nature.com/lm1x4t
NATUREJOBS For the latest career listings and advice www.naturejobs.com

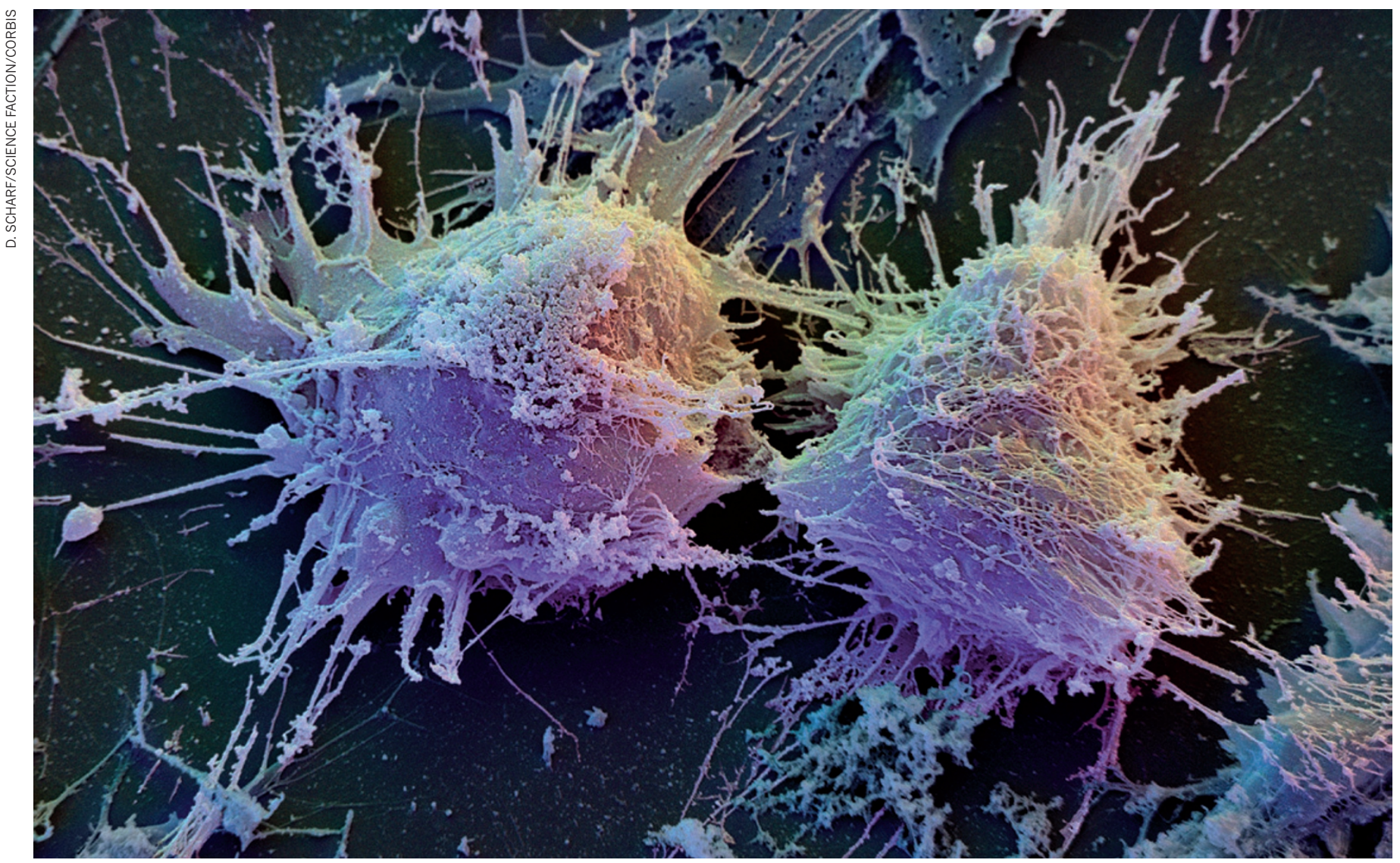

Mastering the growth of human embryonic stem cells, including by methods that use mouse fibroblasts (pictured), continues to spur research opportunities.

\title{
Growing with the flow
}

\section{A US court case is making stem-cell researchers nervous. But the field continues to thrive.}

\section{BY MEREDITH WADMAN}

A s Renée Reijo Pera prepared for a radio interview one late-April morning in her office in Palo Alto, California, she was savouring two pieces of good news. The day before, the faculty senate had unanimously approved a new $\mathrm{PhD}$ programme in stem-cell biology and regenerative medicine at Stanford University's medical school. Reijo Pera will be directing the programme when it starts up this autumn. And just that morning, the US Court of Appeals for the District of Columbia Circuit - one level below the US Supreme Court had thrown out a lower-court injunction. The injunction had blocked the US National Institutes of Health (NIH) from funding research that used human embryonic stem (ES) cells for 17 days last summer - and threatened to derail the funding for good. "I remember saying that good news often seems to come in waves," says Reijo Pera. But, as well as being relieved about the court ruling, she says, she was also wary. "If you're in this field you become a little leery of getting your hopes up. I wanted to know more, to make sure that I had heard correctly."

Reijo Pera had heard correctly, but she was right to be on guard. The ruling is unlikely to be the last chapter in this closely watched case (see Nature 473, 15; 2011). What is more, an ultimate victory in the case, which pitted two scientist activists against the Department of Health and Human Services, would not prevent future presidents or Congresses from acting anew to limit government funding for the research. Surveys suggest that a majority of Americans approve of human-ES-cell research, but there is a vocal opposition that objects to days-old human embryos being destroyed to obtain cell lines, and is willing to wage legal battles to stop research on them. So, although the NIH continues to fund the research - including an estimated US $\$ 125$ million this year - it does not do so with the legal and political security that exists, for 
instance, in the United Kingdom.

Young scientists considering or embarking on careers in stem-cell biology have to come to terms with the uncertainty that surrounds human-ES-cell research funding. But although funding issues can make the career road bumpy, the exploding number of opportunities in the field means that it can still be negotiated with forethought and careful planning.

\section{BE WILLING TO MOVE}

Students choosing a graduate institution or postdoc position, or people seeking a faculty position or industry job (see 'Industry's stemcell possibilities'), should consider looking in the jurisdictions most hospitable to stem-cell research. In the United States, four states California, Connecticut, Maryland and New York - collectively funded more humanES-cell research than the NIH did between 2005 and 2009, and their funding equalled or exceeded the NIH's in 2008 and 2009 (R. N. Karmali, N. M. Jones and A. D. Levine Nature Biotechnol. 28, 1246-1248; 2010). Positions in these states therefore often have access to funding from sources other than NIH grants.

"That's particularly important if you're a young stem-cell scientist in this field," says Aaron Levine, an assistant professor of public policy at the Georgia Institute of Technology in Atlanta. Researchers can thrive in "places where you have alternative streams of funding to protect you if NIH funding gets interrupted again", he says.

Since he arrived at the University of California, San Francisco, in 2008 to begin his second postdoc, Dutch scientist Dennis Van Hoof has been insulated from the vagaries of US stem-cell politics. His buffer is a combination of private foundation grants and infrastructure support from the California Institute for Regenerative Medicine (CIRM) in San Francisco, which is dispersing $\$ 3$ billion on stem-cell research funded by California taxpayers.

CIRM has handed out more than $\$ 428$ million in human-ES-cell science awards. In addition, it has funded more than 200 research-training and career-development

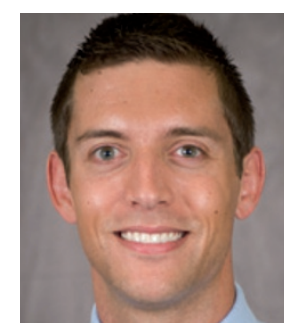

"If stem cells are going to move out of the lab, there will be lots of need for engineers to produce a large number of identical cells." Aaron Levine grants, collectively worth about $\$ 386$ million, since 2006. It has also contributed to new buildings. Van Hoof, who himself has type-I diabetes, is working to produce insulin-secreting pancreatic beta cells from human ES cells to replace those that no longer function in people with diabetes. He works in a brand-new stem-cell research building funded by CIRM, and his grant support has come largely from the Juvenile Diabetes Research Foundation and the Leona M. \& Harry B. Helmsley Charitable Trust, both based in New York. He has never applied for an NIH grant and he intends to keep it that way. "If you have an idea for a grant proposal, federal funding would definitely be second choice," he says.
However, apart from a fairly exclusive stable of labs well supported by private funding, private donors don't begin to approach what the NIH can offer. Scientists often use private money to seed projects for which they hope eventually to win NIH support. And not all private foundations embrace human-ES-cell research. The American Heart Association in Dallas, Texas, for instance, has steered clear of funding it because of the ethical and political controversy involved.

That kind of caution should disappear with time, especially if human ES cells begin to produce results in the clinic, according to some researchers. "I think it will not be long before we see real clinical benefit from this research," argues Martin Pera, who on 1 June became programme leader of Stem Cells Australia at the University of Melbourne. "And once that happens, the opposing voices will diminish in influence."

\section{SAFE HAVENS?}

Stem-cell 'havens' are not always easy to find. Pera - who until last month directed the stem-cell research centre at the University of Southern California in Los Angeles - is returning to his native Australia at a time when Australian government support for the research has been scaled back by just over $70 \%$. At the end of this month, the government will close the Australian Stem Cell Centre, which funded stem-cell research to the tune of Aus $\$ 11$ million (US\$12 million) in the last financial year. In its place, Stem Cells Australia will be funded at Aus \$21 million spread over seven years.

By contrast, at the University of Cambridge, UK, the Cambridge Stem Cell Initiative - an

\section{BRANCHING OUT}

\section{Industry's stem-cell possibilities}

Like academia, industry promises many opportunities for stem-cell researchers but they bring their own uncertainties.

The opportunities come from the many companies working to develop adult stemcell therapies. And in the field of human embryonic stem (ES) cells, businesses in the United States are somewhat insulated, by virtue of their private funding, from the political vagaries that dictate the livelihoods of researchers funded by the US National Institutes of Health (NIH).

But there are uncertainties. Businesses are not immune to tough economic circumstances. In February, for example, Pfizer announced the closure of its threeyear-old Regenerative Medicine unit, which had been developing stem-cell therapies for cardiac disorders and cancer. Its demise eliminated 18 jobs in Cambridge,
Massachusetts. The company's remaining regenerative-medicine work has been folded into a subsidiary in Cambridge, UK, now called Neusentis, where roughly 30 people still work on human ES cells. They focus on topics ranging from creating cell lines for drug discovery to developing cell therapies for diseases such as macular degeneration, a leading cause of blindness.

Before being put off by Pfizer's downsizing, job-seekers should remember that, when it launched Pfizer Regenerative Medicine, the company put itself out on the most vulnerable edge of the humanES-cell research spectrum: bringing cures to the clinic. "Cell therapy is a very risky enterprise for big investment," says John McNeish, former executive director of Pfizer's US regenerative-medicine unit. Still, he remains bullish about the field. "With risk comes reward," he says.

And for every dead end, there's an opportunity. In April, Neusentis announced that in conjunction with Pfizer Canada, it would fund six Can\$50,000 (US\$52,000) postdoctoral fellowships this year and next with the aim of fostering high-calibre stemcell scientists and developing new areas of clinical interest.

Ruth McKernan, Neusentis's chief scientific officer, encourages budding stem-cell scientists - among them her 20-year-old daughter - to consider jobs in industry, especially if they have clinical interests. "In the pharmaceutical industry, you can see how your unique piece of science enables the progress of drugs from research all the way to the clinic," she says. "And it's very difficult to see that spectrum in academia." M.W. 


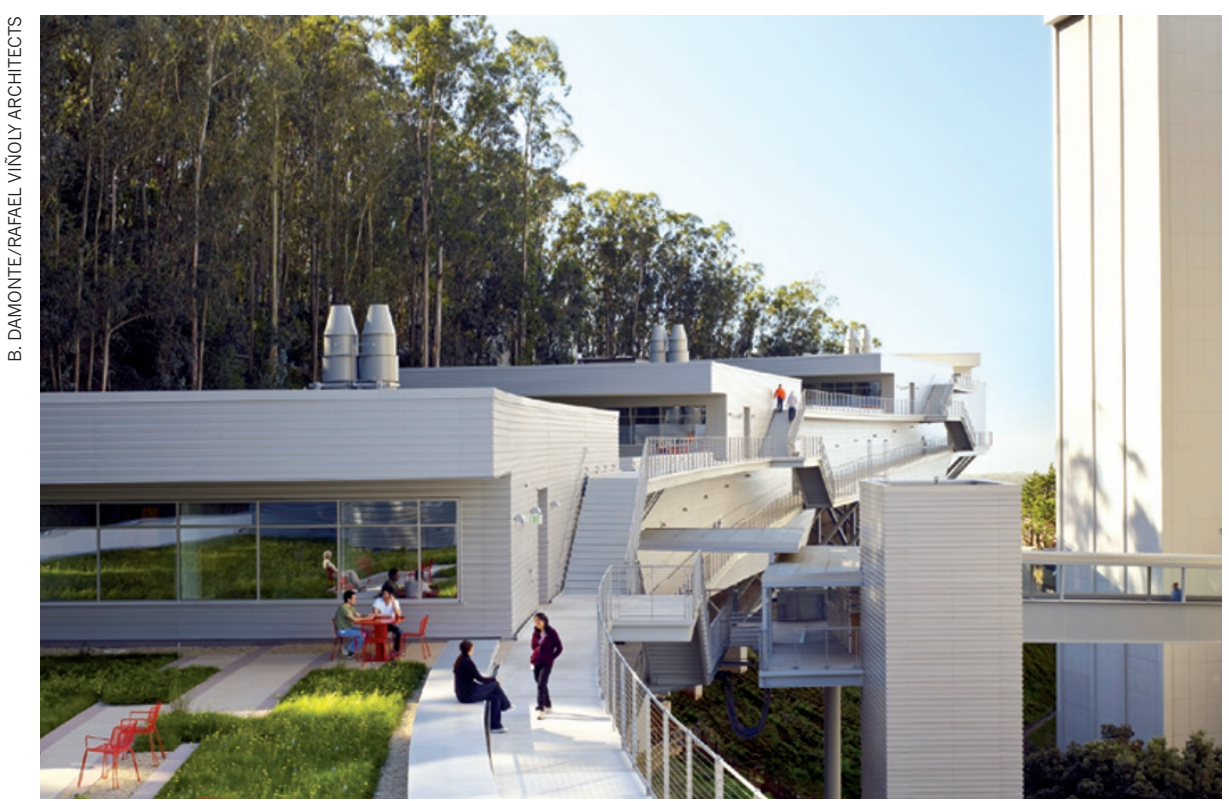

This CIRM-funded stem-cell centre at the University of California, San Francisco, opened in February.

effort launched in 2002 with the lofty goal of becoming Europe's flagship stem-cell research centre - has roughly doubled in size, to about 250 researchers in 25 groups. And "we are actively recruiting at all levels and still growing the initiative", says Roger Pedersen, a human-ES-cell scientist and co-convener of the initiative. Meanwhile, the UK government's Technology Strategy Board has announced plans to open a cell-therapy technology and innovation centre, aimed at spurring commercialization of therapies in the United Kingdom. The board will give it between $£ 20$ million and $£ 40$ million (US\$33 million to $\$ 65$ million) in core funding over the next four years, according to Nick Sheppard, a spokesman for the board, and is expected to raise twice as much again from other sources, both public and private.

Some Britons might actually have an easier time in the United States. That has been the case for Paul Burridge, a British postdoc at the Johns Hopkins Institute for Cell Engineering in Baltimore, Maryland, who is working on deriving heart cells to treat cardiac disease. Drawn, he says, by the ease of obtaining funding from the Maryland Stem Cell Research Fund, and discouraged by difficulties in the United Kingdom, Burridge relocated in 2008 and plans to focus on the less controversial induced pluripotent stem (iPS) cells, which are created not from embryos, but by reprogramming adult cells. "The policy changes that have been made [in the United States] have had a drastic effect on my career," he says.

\section{A DIVERSIFIED PORTFOLIO}

It is a high-risk strategy to focus research solely on ES cells. Fortunately, diversifying has become easier: the advent of iPS cells has generated opportunities for stem-cell scientists that are much less constrained by politics. Researchers hope that human iPS cells, which behave similarly to ES cells, will help them to address basic questions about how undifferentiated cells become heart or muscle cells, as models for studying disease and as targets for drug development. Other options are provided by adult stem cells obtained from various organs. These cells are much less flexible, but come without ethical conundrums. In addition, working with non-human ES cells offers a less-politicized route to studying subjects such as developmental biology. "The field has been opened up and there are many different directions it can be taken," says Timothy Kamp, director of the University of Wisconsin Stem Cell \& Regenerative Medicine Center in Madison. So the legal and political uncertainty around ES cells shouldn't "kill people's career decisions", he says.

The interest in iPS cells, in particular, isn't confined to academia. "Across the industry, this is an area where there is likely to be increased opportunity for young people," says Ruth McKernan, chief scientific officer for Neusentis, a subsidiary of Pfizer based in Cambridge, UK, that conducts the company's stem-cell and regenerative medicine work. The same techniques and science underpin iPS cell biology, so experience working with human ES cells is of increasing value to the pharmaceutical industry, says McKernan.

\section{GET BROAD TRAINING}

The basic intellectual tool kit for scientists entering the field includes a good grounding in cell and molecular biology and some understanding of developmental biology - typical components of undergraduate and graduate programmes. Kamp adds that researchers can make themselves more marketable by honing expertise in techniques beyond cell culture, such as advanced imaging technologies, or metabolomics, the systematic study of all the metabolites present in a cell, tissue, organ or organism.

Although these subjects can be studied in many departments of biology, several institutes now have more targeted programmes. In addition to Stanford's nascent stem-cell PhD, the Sackler Institute of Graduate Biomedical Sciences at New York University School of Medicine is now offering its $\mathrm{PhD}$ students a track specializing in stem-cell biology. The Sackler programme has been helped greatly by a \$1.9-million training grant from the state's stem-cell initiative, says Joel Oppenheim, the senior associate dean for biomedical sciences at the school of medicine. His students, he notes, have not been deterred by the uncertainty around NIH funding. For them, stemcell research "is sort of the new hot buzz topic", he says.

The University of Minnesota in Minneapolis now offers a master's degree in stem-cell biology. And Dan Kaufman, associate director of the university's stem-cell institute, says that he hopes it will become a fully fledged $\mathrm{PhD}$ in stem-cell biology.

Postgraduate programmes are also taking root outside of the United States. In Germany, the Hanover Biomedical Research School in Germany launched a three-year PhD in Regenerative Sciences in 2007 that accepts up to 20 students a year from all over the world. In Britain, The Wellcome Trust Centre for Stem Cell Research and the Medical Research Council together fund a highly competitive four-year doctoral programme at the University of Cambridge, and the University of Sheffield offers a master's degree in stem-cell biology.

Other programmes may provide young researchers with outside-the-box opportunities as the stem-cell field matures. Consider, for instance, the emerging need for biomanufacturers with stem-cell expertise, as exemplified by a new $\mathrm{PhD}$ programme in stem-cell biomanufacturing at the Georgia Institute of Technology, funded by the US National Science Foundation. The programme opened its doors last year and is admitting six students per year. "If stem cells are going to move out of the lab, there will be lots of need for engineers to produce a large number of identical cells," says Levine.

Wherever an aspiring scientist's inclinations point, there should to be plenty of activity and opportunity, politics notwithstanding. And there is certainly plenty of interest. In the first week after Stanford announced its new $\mathrm{PhD}$ - and before she had posted any information about it on the Internet - Reijo Pera received 82 e-mails expressing interest in applying. "This is actually a statement that stem-cell biology and regenerative medicine are here to stay," she says. "It is a discipline with unique skills and training. It is a real entity, not hype."

Meredith Wadman is a Nature correspondent based in Washington DC. 